\title{
Effects of Artisanal Fishing on Marine Communities in the Galápagos Islands
}

\author{
BENJAMIN I. RUTTENBERG* \\ School of Forestry and Environmental Studies, Yale University, New Haven, CT 06511, U.S.A.
}

\begin{abstract}
The Galápagos Islands harbor some of the least impacted marine ecosystems in the tropics, but there are indications that local artisanal fishing is affecting exploited marine communities. To quantify these effects, I sampled communities of fishes and sea urchins at a number of beavily fished and lightly fished sites throughout the central islands of the archipelago. Sites were selected based on information collected as part of a local fisheries monitoring study and standardized across a number of abiotic factors. Abundance and biomass of the primary target species were significantly lower in the beavily fished sites than in the lightly fished sites. Community structure also differed between beavily and lightly fished sites. Cluster analyses of the full community of fishes and a subset of nontarget fishes revealed that sites within a treatment were more similar to one another than sites between treatments. Herbivorous fishes tended to be lower in abundance and sea urchins tended to be bigher in abundance in beavily fished sites, but these differences were not significant. My results are encouraging in that the direct effects of artisanal fishing are limited to the primary target species, which probably results from a bigh specificity of fishing gear. The differences in community structure, bowever, suggest that artisanal fishing also bas cascading effects on noncommercial species throughout the community. An improved understanding of important ecological interactions, increased ecological and fishery monitoring, and effective precautionary management are needed to ensure that buman effects in these waters remain minimal.
\end{abstract}

Efectos de la Pesca Artesanal en Comunidades Marinas en las Islas Galápagos

Resumen: Las Islas Galápagos albergan algunos de los ecosistemas marinos menos afectados en los trópicos, pero bay indicios de que la pesca artesanal afecta a las comunidades marinas explotadas. Para cuantificar estos efectos, se muestrearon las comunidades de peces y erizos de mar en numerosos sitios con pesca intensiva y no intensiva en las islas centrales del archipiélago. Los sitios fueron seleccionados con base en la información colectada como parte de un estudio de monitoreo de pesquerías locales y estandarizada para diversos factores abióticos. La abundancia y la biomasa de las principales especies explotadas fue significativamente menor en los sitios con pesca intensiva versus no intensiva. La estructura de la comunidad también fue diferente para sitios. El análisis de cluster de la comunidad total de peces y de un subconjunto de peces no explotados reveló que los sitios dentro de un tratamiento eran más similares entre sí que los sitios entre tratamientos. Los peces berbívoros tendieron a una menor abundancia y los erizos tendieron ser más abundantes en sitios con pesca intensiva, pero estas diferencias no fueron significativas. Mis resultados son alentadores en cuanto que los efectos directos de la pesca artesanal están limitados a las principales especies explotadas, lo que probablemente resulte de una alta especificidad de las artes de pesca. Sin embargo, las diferencias en la estructura de la comunidad sugieren que la pesca artesanal tiene efectos en cascada en la comunidad de especies no comerciales. Se requiere de un mejor entendimiento de las interacciones ecológicas importantes, de un incremento del monitoreo ecológico y de pesquerías, así como de manejo efectivo y precautorio para asegurar que los efectos humanos en estas aguas sigan siendo mínimos. 


\section{Introduction}

The Galápagos Islands contain some of the most unique and historically significant terrestrial island ecosystems, made famous as one of the inspirations for Charles Darwin's theory of natural selection. But the equally unique and diverse marine ecosystems surrounding the islands have received considerably less protection and attention. Over the last half-century, these marine systems have been increasingly threatened as the human population of Galápagos has increased (Merlen 1995). Although direct human effects on the physical environment such as pollution and alteration or destruction of inshore habitats have increased over the last few decades, these effects have tended to be localized near the three small fishing ports in Galápagos (Broadus \& Gaines 1987; MacFarland \& Cifuentes 1996). Other threats to marine environments around the archipelago come from local artisanal fishers, defined as small-scale fishing using simple technology, such as hand lines and hand nets (Camhi 1995; Merlen 1995; MacFarland \& Cifuentes 1996). I sought to determine the potential effect of the hook-and-line fishery on the communities of fishes it exploits.

The effects of artisanal fishing on marine communities have been studied extensively in a variety of tropical reef ecosystems. The most obvious of these effects involve target species, defined as those species sought and caught by fishers. Decreases in abundance and biomass of target species have been detected in a number of different areas throughout the tropics (e.g., Koslow et al. 1988; Russ \& Alcala 1989; Jennings et al. 1995; Jennings \& Polunin 1996a; McClanahan et al. 1999). Commercial species often include the higher predators, such as the serranids (groupers), lutjanids (snappers), and balistids (triggerfishes), and their removal can have cascading effects throughout the food web (Beddington \& May 1982; Koslow et al. 1988; Jennings \& Kaiser 1998; Sala et al. 1998; McClanahan et al. 1999). Evidence of cascading effects on nontarget species has been found in some systems (Watson \& Ormond 1994; McClanahan et al. 1996; Jennings \& Polunin 1997) but not in others (Russ \& Alcala 1989; Jennings \& Polunin 1996a, 1997). Nonselective fishing gear, such as explosives or traps, can also modify or destroy habitat and remove individuals of many different species (Russ 1991; Jennings \& Polunin 1996b; Jennings \& Kaiser 1998).

Fishing can also have indirect effects on sea urchin populations if target species are important urchin predators (e.g., McClanahan et al. 1996; Sala \& Zabala 1996; McClanahan 1998; Sala et al. 1998). Predator densities are reduced through fishing, allowing their urchin prey to proliferate; a positive correlation between sea urchin abundance and fishing pressure has been detected in both tropical and temperate systems (McClanahan \& Muthiga 1988; Watson \& Ormond 1994; Sala \& Zabala 1996; McClanahan et al. 1999). Increases in sea urchin densities may also affect densities of herbivorous fishes, because the urchins are able to outcompete fishes for algal resources (McClanahan \& Kaunda-Arara 1996; McClanahan et al. 1996).

There are some indications that fishing has had effects on exploited communities in Galápagos. As recently as a decade ago, the bacalao (Mycteroperca olfax), a large grouper, was the most valuable and exploited fish in the artisanal fishery (Kasteleijin 1987), comprising over $40 \%$ of the catch (Reck 1983). M. olfax may now comprise $<20 \%$ of the catch, and fishers themselves indicate that the catch per unit effort and the average size of individual fish have declined (Bustamante 1998, and unpublished data). Sightings and size of $M$. olfax have also declined in situ, whereas the abundance of sea urchins, particularly Eucidaris thouarsii, has increased dramatically in recent years (R. H. Bustamante, personal communication; G. M. Wellington, personal communication).

To determine the effects of fishing on marine communities in the Galápagos, I surveyed communities of fishes and sea urchins at a number of sites that varied in fishing pressure. For a variety of reasons, some areas in the Galápagos are fished more heavily than others. Areas that are difficult to reach or far from other potential sites tend to be fished only lightly, and the Galápagos National Park Service prohibits fishing near tourist sites. In contrast, areas near ports or near other fishing sites tend to be fished more heavily. I hypothesized that target species in heavily fished areas would have lower abundance and biomass, and that the community structure of fishes in these areas would differ from that of lightly fished areas. Based on patterns observed in other areas (e.g., McClanahan \& Muthiga 1988; Sala \& Zabala 1996; McClanahan et al. 1999), I expected to find an increase in sea urchin abundance in heavily fished areas over that of lightly fished areas.

\section{Methods}

\section{Study System}

Environmental conditions are highly variable in Galápagos because the islands sit at the confluence of a number of ocean currents and at the epicenter of the El Niño phenomenon (Houvenaghel 1984). Strong seasonality also exists, with a short warm season from December to April, followed by a longer cold season that generally lasts from May to November; differences in sea surface temperature between seasons may be $8^{\circ} \mathrm{C}$ or more (Houvenaghel 1984). Five hydrogeographic zones exist in the archipelago, as determined by water temperature (Harris 1969), and fish assemblages roughly cluster in these zones (Wellington 1984; Jennings et al. 1994). To control for this variation and simplify logistics, I attempted to select all my study sites from within the central zone that 
surrounds Santa Cruz Island and the Charles Darwin Research Station (Fig. 1). Because substrate slope and benthic complexity can also influence communities of fishes and sea urchins, I elected to sample only those sites with a flat or shallow slope and high benthic complexity (McCormick \& Choat 1987; McClanahan \& Shafir 1990).

Artisanal fishers in Galápagos employ various fishing methods, but only two affect the rocky reef habitats I sampled. Spearfishing, illegal in the Galápagos but still practiced, makes an unknown contribution to the fishery, because catch from spearfishing is only occasionally reported ( $R$. H. Bustamante, personal communication; personal observation). Fishing with hand lines and baited hooks (called empate) is the principal method used over the rocky reefs. Although this method is fairly guild-specific and tends to capture only the higher predators, there is some bycatch of other species with little commercial value. In the central islands at shallow depths, six species (four serranids and two lutjanids) comprise nearly all the catch and are the only commercially valuable species seen at the study sites.

\section{Selection of Study Sites}

To select sites appropriate for sampling, I analyzed data from the fisheries monitoring study of the Darwin Station (Bustamante 1998, unpublished data). I generated a frequency distribution of fishing trips per site, including only those trips that used hand lines or spearguns, keeping in mind that most spearfishing trips are not reported. I considered sites in the top quartile to be heavily fished and sites in the bottom quartile to be lightly fished, but

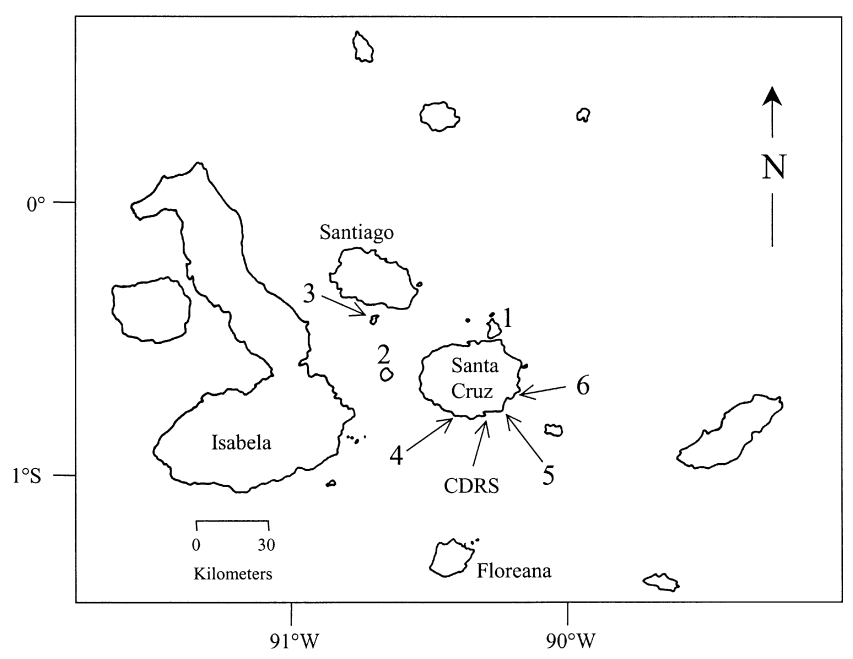

Figure 1. The central islands of the Galápagos Archipelago. Sites 1-3 are lightly fished (1, Mosquera; 2, Pinzón; 3, Rábida), and sites 4-6 are beavily fished (4, La Torta; 5, Punta Nuñez; 6, Punta Rocafuerte) (CDRS; Charles Darwin Research Station). the data from the fisheries monitoring study were not sufficiently complete to quantify fishing pressure at each site. To corroborate information from the fisheries monitoring study, I interviewed fishers and visited sites with them to determine which were intensively used and which were not. Only sites for which information generated from the monitoring study matched information given by fishers were considered further. Finally, after sampling a number of sites for habitat type to ensure that sites were as similar as possible, I selected three heavily fished sites and three lightly fished sites. Each site encompassed approximately $1-2 \mathrm{~km}$ of coastline. Five out of six sites were in the central hydrogeographic zone of Santa Cruz Island. One lightly fished site, Rábida, was outside but on the border of the central zone, and water temperatures there at the time of sampling were consistent with temperatures at the other sites.

\section{Survey of Reef-Fish Population Densities}

All surveys were made between 17 June and 12 August 1998, after the onset of the cold season (Houvenaghel 1984). The heavily fished sites near the Darwin Station were surveyed on single day trips staggered over the course of the 2-month sampling period. Because the lightly fished sites were farther from port, logistical considerations prevented more than one visit during the study, but each site was sampled intensively over the course of individual week-long trips.

I made quantitative abundance estimates of fishes through underwater visual surveys (e.g., Jennings et al. 1995; Samoilys 1997). Using a point-count technique modified from Samoilys (1997), I sampled only in areas of appropriate habitat type and complexity within each site. In each count (hereafter referred to as a replicate), I estimated the abundance of all diurnally active, reef-associated fishes larger than $10 \mathrm{~cm}$ in a circle of radius $6.9 \mathrm{~m}$ (area of $150 \mathrm{~m}^{2}$ ). During each survey, I estimated the size of all individuals of commercial species to the nearest $5 \mathrm{~cm}$ (e.g., the $40-\mathrm{cm}$ size class included individuals that ranged from approximately 37.5 to $42.5 \mathrm{~cm}$ ). Prior to sampling, I developed the ability to estimate size accurately by practicing with segments of plastic tube cut into lengths that ranged from 10 to $100 \mathrm{~cm}$ in $5-\mathrm{cm}$ increments, to a success rate of over $80 \%$.

A dive assistant and I conducted all sampling. I indicated a spot haphazardly on the substrate to begin the first replicate (depth approximately $12 \mathrm{~m}$ ). The dive assistant laid one end of a weighted 6.9-m line and swam along a constant depth contour to place the other end of the line. While my assistant laid the line, I began the survey using the first spot I indicated as the center of the circle. I started the count in the direction of my assistant, beginning with the most wary, active species to reduce the effects of his presence on counts (Sale \& Sharp 
1983; Watson et al. 1995). I proceeded to more territorial species while remaining near the center of the circle and ended by swimming once around the circle near the edge to count sedentary species associated with the benthos. During the count, I used the line as a guide to estimate the radius of the circle. Only those individuals in the circle when the count began were included, and once all individuals of a species had been counted, all further movements of individuals of that species were ignored for the duration of that replicate. Each replicate lasted approximately 5 minutes.

I recorded environmental data for each replicate after completing the fish count. These data included horizontal visibility, depth, and water temperature. I used a relative scale of 0 to 3 to estimate current, substrate complexity, and substrate gradient. For current, 0 was no current and 3 was a strong current (approximately 2-3 knots). For complexity, 0 represented an area with fewer cracks and fissures in the rock, and 3 represented an area with many cracks and fissures in the rocks. Two dive sites near the Darwin Station were used as standards for a score of 0 and a score of 3 . For gradient, 0 was flat and a 3 was a slope of approximately $30^{\circ}$, estimated by eye. I collected all environmental data, so any bias was consistent across all replicates and sites.

After completing each replicate, we swam at a constant depth for approximately 50 fin beats before beginning the next replicate. The number of replicates ranged from 24 to 42 per site. We completed at least 35 replicates for each site except La Torta $(n=24)$, for which we had to suspend surveys because of poor water visibility and rough conditions during the last few weeks of the sampling period.

\section{Survey of Sea Urchin Population Densities}

Sea urchin densities were surveyed with a methodology modified from McClanahan and Shafir (1990) and a study conducted by Bustamante et al. (unpublished data) at the Darwin Station. We chose plots within each site to include only those areas of relatively high benthic complexity, with many cracks and fissures in the rocks into which urchins can wedge themselves (McClanahan \& Shafir 1990). A center point for each plot was selected haphazardly, from which a line of fixed radius was rotated (radius of $1.26 \mathrm{~m}$, total area $5 \mathrm{~m}^{2}$ ). As we rotated the line, all sea urchins within the area circumscribed by the line were identified and counted. Depth was recorded for each plot. After completing a plot, the diver moved along the contour line approximately $5 \mathrm{~m}$, chose another center point, and surveyed the next plot. Sea urchin plots at the heavily fished sites near Darwin Station were sampled by single-day trips, whereas lightly fished sites were sampled during the same week-long trips when fish communities were sampled. Between 14 and 68 plots were sampled at each site.

\section{Analyses and Statistics}

Each species of fish was classified as either a target or nontarget species based on (1) its susceptibility to handline and spearfishing, (2) analysis of species-specific catch data from the Darwin Station's fisheries monitoring study, and (3) available literature (Allen 1985; Heemstra \& Randall 1993; Grove \& Lavenberg 1997; R. H. Bustamante, unpublished data). Species were also placed into trophic groups based on their method of feeding and preferred food items (Allen 1985; Heemstra \& Randall 1993; Grove \& Lavenberg 1997). Rare species and species that are not permanent residents of reefs, such as pelagics that occasionally swim over reefs, were excluded from all analyses. Only two commercially valuable species were excluded: mullet snapper (Lutjanus aratus), because only one individual was counted in one transect during the course of the entire study, and stone scorpionfish (Scorpaena mystes), because its cryptic coloration makes it difficult to see.

A number of nontarget species were excluded for a variety of reasons other than rarity. Parantbias colonus and Abudefduf sp. were excluded because they are associated with the substrate but also swim high in the water column in high densities. All species in the genus Stegastes were excluded because they occur in high densities, are cryptically associated with the benthos, and are small (often $<10 \mathrm{~cm}$ ). After initial inspection and analysis of the data, I included 34 species in the analysis ( Table 1). I calculated the biomass of each individual of the commercial species with length-weight relationships drawn from the literature and from the fisheries monitoring study of the Darwin Station (Froese \& Pauly 1998; R. H. Bustamante, unpublished data), using the midpoint of each size class as the estimate of length.

I analyzed overall community similarity with a BrayCurtis similarity, using the cluster-analysis option within the Primer software package (Clarke \& Warwick 1994), which groups sites based on analyses of similarities of the entire community assemblage. I calculated and double-log-transformed (Jennings et al. 1994) the mean density for each of the 34 species at each site to create a site-by-species matrix for use in cluster analyses.

\section{Results}

Analysis of habitat variables revealed no significant differences between treatments for any variable except gradient. Gradient was significantly steeper in lightly fished than in heavily fished sites ( $t$ test: $t=4.44$, df $=$ $4, p<0.05 ; p>0.10$ for all other variables). But separate within-treatment regression analyses revealed that no significant relationships existed between gradient and density or biomass of commercial species, nor between 
Table 1. List of species of heavily fished and lightly fished areas off Galápagos Islands and their trophic level used in analysis. ${ }^{a}$

\begin{tabular}{|c|c|c|c|}
\hline Family and species & Tropbic group & Family and species & Tropbic group \\
\hline Acanthuridae & & Lutjanus argentiventris & 1 \\
\hline Acantburus xantbopterus & 4 & L. novemfasciatus & 1 \\
\hline Prionurus laticlavius & 4 & L. viridis & 1 \\
\hline Aulostomidae & & Mullidae & \\
\hline Aulostomus chinensis & 1 & Mulloidichthys dentautus & 1 \\
\hline Balistidae & & Pomacanthidae & \\
\hline Sufflamen verres & 2 & Holacantbus passer & 3 \\
\hline Chaetodontidae & & Pomacentridae & \\
\hline Chaetodon bumeralis & 3 & Microspatbodon dorsalis & 4 \\
\hline \multirow[t]{2}{*}{ Jobnrandallia nigrirostris } & 3 & & \\
\hline & & Scaridae & \\
\hline \multicolumn{4}{|l|}{ Diodotidae } \\
\hline \multirow{2}{*}{ Diodon bolocanthus } & 2 & Scarus compressus & 4 \\
\hline & & S. gbobban & 4 \\
\hline \multicolumn{4}{|l|}{ Girellidae } \\
\hline \multirow[t]{2}{*}{ Girella freminvillei } & 4 & S. perrico & 4 \\
\hline & & S. rubroviolaceus & 4 \\
\hline \multicolumn{4}{|l|}{ Haemulidae } \\
\hline Anisotremus interruptus & 2 & Sciaendae & \\
\hline Haemulon scudderi & 2 & Sciaenidae $^{b}$ & 1 \\
\hline H. sexfasciatum & 2 & & \\
\hline \multirow[t]{2}{*}{ Orthopristis forbesi } & 2 & Serranidae & \\
\hline & & Alphastes immaculatus & 1 \\
\hline \multicolumn{4}{|l|}{ Kyphosidae } \\
\hline \multirow[t]{2}{*}{ Kypbosus analogus } & 3 & Dermatolepis dermatolepis & 1 \\
\hline & & Cepbalopbolis panamensis & 1 \\
\hline Labridae & & Epinepbelus labriformis & 1 \\
\hline Bodianus diplotaenia & 2 & Mycteroperca olfax & 1 \\
\hline \multirow[t]{2}{*}{ Halichoeres nicholsi } & 2 & & \\
\hline & & Tetraodontidae & \\
\hline Lutjanidae & & Arotbron meleagris & 2 \\
\hline Hoplopagrus guentheri & 1 & Spboeroides annulatus & 2 \\
\hline
\end{tabular}

${ }^{a}$ Trophic groups: 1, piscivore and invertivore; 2 , invertivore; 3, herbivore and invertivore; 4 , berbivore.

${ }^{b}$ Observed individuals in the family Sciaenidae were either Corvula macrops or Odontoscion eurymesops, which are difficult to distinguish underwater.

gradient and density of noncommercial species $(p>0.10$ in all cases). All habitat variables were therefore omitted from subsequent analyses.

When aggregated across all commercial species for each site, density and biomass were significantly lower in heavily than in lightly fished sites ( $t$ test: $t=5.15$, df $=4, p<0.01$ for density; $t=6.15$, df $=4, p<0.005$ for biomass; Fig. 2). When analyzed individually, most commercial species showed decreases in abundance and biomass in heavily versus lightly fished sites, but only those for $M$. olfax were significantly different (Table 2). A consensus-combined $p$-value test (Rice 1990) based on one-tailed tests revealed that the trend over all six commercial species was significant (consensus-combined $p$-value test: $p<0.005)$. Two of the six most abundant noncommercial species differed significantly between heavily fished and lightly fished sites (Table 3). Twotailed tests were used because I had no a priori expectations about the directionality of possible changes. Bodi- anus diplotaenia was lower in abundance in fished areas ( $t$ test; $t=2.92$, df $=4, p<0.05$ ), whereas Halichoeres nicholsi was higher in abundance in fished areas ( $t$ test: $t=2.94$, df $=4, p<0.05$ ). A consensuscombined $p$-value test (Rice 1990) indicated that there was no trend toward lower abundance of noncommercial species as a group (consensus-combined $p$-value test: $p=0.61$ ).

Cluster analysis of the full community showed that sites fell into two main groups that correspond perfectly to fishing pressure (Fig. 3a). In a similar analysis performed on the subset of nontarget species (with the commercial species deleted from the matrix), the heavily fished sites still clustered together on one branch, but only two of the lightly fished sites clustered together (Fig. 3b). To determine the effects of fishing on each trophic level, I calculated the mean density for each trophic level for each site. Both piscivores/invertivores and herbivorous fishes were lower in abundance in 


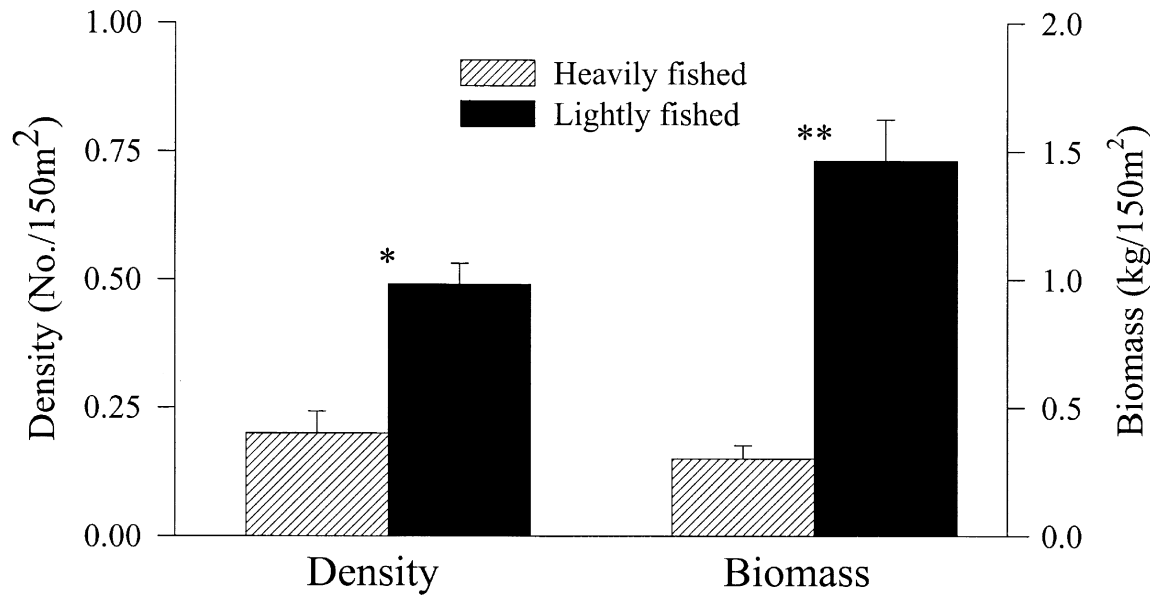

Figure 2. Density and biomass of commercial species (mean $\pm 1 S E$ ). One asterisk indicates significance at the 0.01 level; two asterisks indicate significance at the 0.005 level. heavily fished than in lightly fished sites, as predicted, but these differences were not statistically significant. No differences existed for species richness between treatments.

Only three species of sea urchins were observed during the study: Eucidaris thouarsii, Tripneustes depressus, and Diadema mexicanum; of these, E. thouarsii comprised nearly $99 \%$ of all urchins surveyed. Because of its overwhelming abundance, only $E$. thouarsii was included in subsequent analyses. I calculated mean density of $E$. thouarsii for each site, and although densities were higher in heavily than in lightly fished sites, the differences were not significant.

\section{Discussion}

The strongest effects of fishing I detected were direct effects on the target species. Although this result seems driven by decreases in the density and biomass of the primary target species, $M$. olfax, the other commercial species as a group demonstrated a significant downward trend. The strong response of $M$. olfax could be a result of a number of factors. As the numerically dominant and most valuable species caught in the hand-line fishery, it is the most directly targeted. It is a more active swimmer than most of the other commercially valuable species and may be more likely to take a hook (Grove \& Lavenberg 1997; R. H. Bustamante, personal communication; personal observation). These factors, along with data from the Darwin Station monitoring program, seem to indicate that this fishery is fairly selective. Most other tropical reef fisheries are much less selective, using traps that remove biomass indiscriminately in all trophic groups and size classes or cyanide or dynamite that destroy habitat (e.g., Koslow et al. 1988; Jennings \& Polunin 1996b; McClanahan \& Kaunda-Arara 1996; Jennings \& Kaiser 1998). In Galápagos, these fishing methods are not used. The selectivity of hand lines for higher predators-and selectivity of spearguns for only the largest fish, to the extent that they are used-may help limit the direct effects of fishing to the primary target species.

There are signs, however, that removal of higher predators may have cascading effects on community structure. Heavily fished sites clustered together when I analyzed them using both the full community and a subset of only nontarget fishes. This could be an indication that fishing reduces the natural between-site variation in the Galápagos. In this scenario, the natural variability of the community structure of fishes in Galápagos decreased when sites were subjected to heavy fishing pressure. Such a decrease in variability could be driven by predictable changes in certain species which either directly or indirectly result from fishing. It is unlikely that these dif-

Table 2. Biomass and density of the six commercial fish species in heavily and lightly fished sites (mean $\pm 1 \mathrm{SE}) .^{*}$

\begin{tabular}{|c|c|c|c|c|c|c|}
\hline \multirow[b]{2}{*}{ Species } & \multicolumn{3}{|c|}{ Biomass $\left(\mathrm{g} / 150 \mathrm{~m}^{2}\right)$} & \multicolumn{3}{|c|}{ Density $\left(\right.$ no. $\left./ 150 \mathrm{~m}^{2}\right)$} \\
\hline & lightly fished & beavily fished & $\mathrm{p}$ & lightly fished & beavily fished & $\mathrm{p}$ \\
\hline Cepbalopbolis panamensis & $432 \pm 174$ & $172 \pm 34.4$ & 0.006 & $0.32 \pm 0.085$ & $0.143 \pm 0.024$ & 0.06 \\
\hline Epinephelus labriformis & $3370 \pm 1232$ & $1700 \pm 262$ & $<0.10$ & $1.18 \pm 0.26$ & $1.23 \pm 0.18$ & $>0.10$ \\
\hline Lutjanus argentiventris & $811 \pm 811$ & $72.8 \pm 56.6$ & $>0.10$ & $0.263 \pm 0.263$ & $0.047 \pm 0.017$ & $>0.10$ \\
\hline
\end{tabular}

*The $\mathrm{p}$ values are for one-tailed $\mathrm{t}$ tests between treatments. 
Table 3. Density of the six most abundant noncommercial species of fishes in heavily and lightly fished sites in decreasing order of mean abundance (no./150 $\left.\mathrm{m}^{2} \pm 1 \mathrm{SE}\right){ }^{*}$

\begin{tabular}{|c|c|c|c|}
\hline Species & $\begin{array}{l}\text { Lightly } \\
\text { fisbed }\end{array}$ & $\begin{array}{l}\text { Heavily } \\
\text { fisbed }\end{array}$ & $\mathrm{p}$ \\
\hline Prionurus laticlavius & $9.17 \pm 4.60$ & $1.85 \pm 0.36$ & $>0.10$ \\
\hline $\begin{array}{l}\text { Bodianus diplotaenia } \\
\text { Anisotremus }\end{array}$ & $4.46 \pm 0.60$ & $2.61 \pm 0.28$ & 0.04 \\
\hline interruptus & $2.02 \pm 0.43$ & $3.27 \pm 0.93$ & $>0.10$ \\
\hline Ortbopristis forbesi & $0.62 \pm 0.53$ & $2.48 \pm 1.10$ & $>0.10$ \\
\hline Haemulon scudderi & $2.84 \pm 1.19$ & $0.96 \pm 0.07$ & $>0.10$ \\
\hline Halichoeres nicholsi & $0.66 \pm 0.07$ & $1.78 \pm 0.38$ & 0.04 \\
\hline
\end{tabular}

*The $\mathrm{p}$ values are for a two-tailed test.

ferences are the result of only direct effects, because noncommercial species exhibited no abundance trend as a function of fishing pressure.

For logistical reasons, sites within treatments were somewhat spatially clumped. The sites along the southern shore of Santa Cruz near the port where the Darwin Station is located are the most heavily fished areas in the central zone, because they are most accessible to fishers. Lightly fished sites were further away, situated in the north of the central zone. Despite this clumping, it is unlikely that biogeographic affinities influence community structure of reef fishes over such small scales. Dominant currents during the cold season come from the south, and all sites had some exposure to these currents. Analysis of habitat variables showed that significant differences between treatments existed only for gradient, but there was no relationship between gradient and fish densities. Furthermore, it has been suggested that, in similar habitats, temperature is the most important factor determining fish assemblages in the Galápagos (McCosker \& Rosenblatt 1984; Grove \& Lavenberg 1997). Jennings et al. (1994) found that fish assemblages differed much more between the cold western zone and the warm northern zone than within the mixed central zone.

Although differences were not significant, densities of the sea urchin $E$. thouarsii showed increasing trends in heavily versus lightly fished sites, whereas herbivorous fishes showed the opposite trend ( Fig. 4). Two potential predators of sea urchins, Bodianus diplotaenia and Arothron meleagris, were significantly less abundant in heavily fished areas. B. diplotaenia was the second most abundant noncommercial species (Table 3), but $A$. meleagris was uncommon even in the lightly fished sites. Other potential predators of sea urchins (Diodon bolocanthus, Sphoeroides annulatus, and Sufflamen verres) showed no trend between heavily and lightly fished sites. B. diplotaenia is one of the largest wrasses in the Galápagos and is known to prey on E. thouarsii (R. H. Bustamante, personal communication; personal observation). Decreases in this species may lead to an increase in its urchin prey and a subsequent decrease in competi-


Figure 3. Dendrograms showing site groupings based on Bray-Curtis similarity analyses of (a) the full community of fishes, commercial and noncommercial, and (b) the subset of noncommercial fishes only. Site numbers (1-6) and fishing-pressure treatment follow those of Fig. 1.

tively inferior herbivorous fishes (McClanahan \& Muthiga 1988; McClanahan et al. 1996). B. diplotaenia is taken as by-catch in unknown quantities (R. H. Bustamante, unpublished data), and it is possible that this catch is affecting local populations and their ability to regulate sea urchin densities.

Although other factors contribute to variability in communities of fishes in Galápagos, evidence presented here suggests that artisanal fishing has both direct and cascad- 


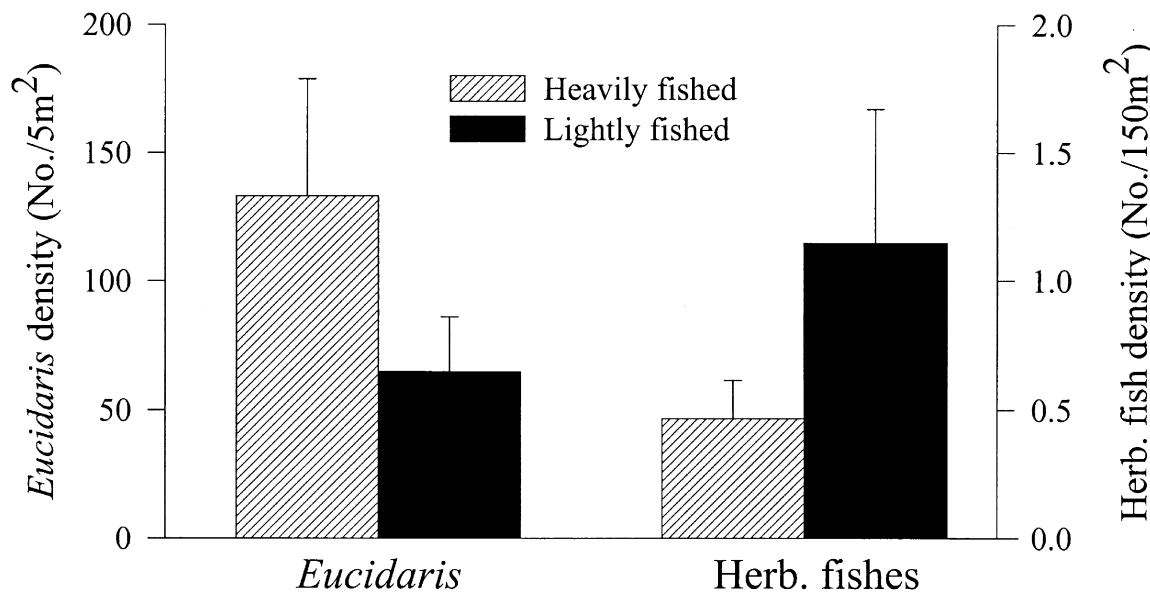

Figure 4. Densities of the sea urchin Eucidaris thouarsii and a guild of herbivorous fishes in beavily and lightly fished sites (mean \pm $1 S E)$. Herbivorous fish density is number of individuals $/ 150 \mathrm{~m}^{2}$ in beavily and lightly fished sites. ing effects throughout the community. The magnitude, rate, and severity of these changes are still unknown. Both direct and indirect effects often have large lag times that may be obscured by variability in recruitment (Beddington \& May 1982; Sissenwine 1984). Single-species population declines and changes in community structure may become apparent only after source populations drop and changes become irreversible (Russ 1991). In addition, the Galápagos Islands have been inhabited and actively exploited for $<50$ years, far less time than most areas of the tropics where the effects of fishing have been studied (Merlen 1995; Jackson 1997). Changes precipitated by the initial exploitation of a pristine ecosystem are likely to be more drastic than those observed after prolonged exploitation (Jennings \& Polunin 1996a; Jackson 1997), but the lag time for these effects is also unknown. Changes in the abundance of $M$. olfax and two abundant noncommercial species and trends in a number of other commercial species, herbivorous fishes, and sea urchins may be the first indications of shifts in community structure resulting from a relatively brief history of exploitation.

No information is available from which to estimate the carrying capacity or productivity of this fishery, and historical data with which to generate a time series are also not available. Although it is encouraging that the most obvious effects of artisanal fishing in Galápagos are limited to the primary commercial species, it remains unclear how serious this effect is and what cascading effects it may have in the present or future. The Galápagos Islands contains a unique tropical marine ecosystem and one of the few that has not been severely altered by human use. This study provides the first evidence of community-level changes associated with exploitation. An improved understanding of the interactions that structure communities, vigilant ecological and fishery monitoring programs, and effective precautionary management are vital to the sustainability of exploitation of marine resources in Galápagos and other tropical reef systems.

\section{Acknowledgments}

This work was supported by grants from the Tropical Resources Institute of Yale University, Project AWARE Foundation of PADI, and a grant-in-aid of research from Sigma Xi, the scientific research society. The Charles Darwin Research Station generously assisted with logistics and equipment. I thank R. Bustamante, former head of the Area of Marine Investigations of the Darwin Station, for his encouragement, understanding, patience, and access to unpublished data. I thank the entire Area of Marine Investigations and staff of the Darwin Station for their support. For their invaluable assistance in the field, I am especially grateful to E. Claflin and K. Doyle. In addition, I thank R. Bustamante, T. Gregoire, D. Skelly, A. Beckerman, and W. Rice for their assistance with data analysis and statistics. I am also indebted to A. Beckerman, D. Skelly, R. Warner, C. Roberts, and three anonymous reviewers for their helpful comments and suggestions on earlier versions of this paper.

\section{Literature Cited}

Allen, G. R. 1985. Food and Agriculture Organization species catalogue 125. Volume 6. Snappers of the world. Food and Agriculture Organization of the United Nations, Rome.

Beddington, J., and R. May. 1982. The harvesting of interacting species in a natural ecosystem. Scientific American 247:62-69.

Broadus, J., and A. Gaines. 1987. Coastal and marine area management in the Galápagos Islands. Coastal Management 15:75-88.

Bustamante, R. H. 1998. The artisanal fishing sector of the Galápagos and the 1997 fishing season. Pages 25-29 in World Wildlife FundFundación Natura, editors. Galápagos report 1997-1998. Trama Publishers, Quito, Ecuador.

Camhi, M. 1995. Industrial fisheries threaten ecological integrity of the Galápagos Islands. Conservation Biology 9:715-724.

Clarke, K. R., and R. M. Warwick. 1994. Change in marine communities: an approach to statistical analysis and interpretation. Plymouth Marine Laboratory and Natural Environment Research Council, Plymouth, United Kingdom.

Froese, R., and D. Pauly. 1998. Fishbase:a biological database on fish. 
International Center for Living Aquatic Resources Management, Makati City, Philippines.

Grove, J. S., and R. J. Lavenberg. 1997. The fishes of the Galápagos Islands. Stanford University Press, Stanford, California.

Harris, M. 1969. Breeding seasons of sea birds in the Galápagos Islands. Journal of Zoology 159:145-165.

Heemstra, P. C., and J. E. Randall. 1993. Food and Agriculture Organization species catalogue 125 . Volume 16 . Groupers of the world. Food and Agriculture Organization of the United Nations, Rome.

Houvenaghel, G. 1984. The oceanographic setting of the Galápagos Islands. Pages 43-54 in J. E. Treherne and R. Perry, editors. Key environment series: Galápagos Islands. Pergamon Press, Oxford, United Kingdom.

Jackson, J. B. C. 1997. Reefs since Columbus. Coral Reefs 16(supplement):S23-S32.

Jennings, S., and M. Kaiser. 1998. The effects of fishing on marine ecosystems. Advances in Marine Biology 34:201-352.

Jennings, S., and N. V. C. Polunin. 1996a. Effects of fishing effort and catch rate upon the structure and biomass of Fijian reef fish communities. Journal of Applied Ecology 33:400-412.

Jennings, S., and N. V. C. Polunin. 1996b. Impacts of fishing on tropical reef ecosystems. Ambio 25:44-49.

Jennings, S., and N. V. C. Polunin. 1997. Impacts of predator depletion by fishing on the biomass and diversity of non-target reef fish communities. Coral Reefs 16:71-82.

Jennings, S., A. Brierley, and J. Walker. 1994. The inshore fish assemblages of the Galápagos Archipelago. Biological Conservation 70: $49-57$.

Jennings, S., G. Grandcourt, and N. V. C. Polunin. 1995. The effects of fishing on the diversity, biomass, and trophic structure of Seychelle's reef fish communities. Coral Reefs 14:225-235.

Kasteleijin, H. 1987. Marine biological research in the Galápagos: past, present, and future. Oceanus 30(2):33-41.

Koslow, J., F. Hanley, and R. Wicklund. 1988. Effects of fishing on reef fish communities at Pedro Bank and Port Royal Cays, Jamaica. Marine Ecology Progress Series 43:201-212.

MacFarland, C., and M. Cifuentes. 1996. Case study: Galápagos, Ecuador. Pages 135-188 in V. Dompka, editor. Human population, biodiversity, and protected areas: science and policy issues. American Association for the Advancement of Science, Washington, D.C.

McClanahan, T. R. 1998. Predation and the distribution and abundance of tropical sea urchin populations. Journal of Experimental Marine Biology and Ecology 221:231-255.

McClanahan, T. R., and B. Kaunda-Arara. 1996. Fishery recovery in a coral-reef marine park and its effect on the adjacent fishery. Conservation Biology 10:1187-1199.

McClanahan, T. R., and N. A. Muthiga. 1988. Changes in Kenyan coral reef community structure and function due to exploitation. Hydrobiologia 166:269-276.

McClanahan, T. R., and S. Shafir. 1990. Causes and consequences of sea urchin abundance and diversity in Kenyan coral reef lagoons. Oecologia 83:362-370.

McClanahan, T. R., A. T. Kamukuru, N. Muthiga, M. Gilagabher Yebio, and D. Obura. 1996. Effect of sea urchin reductions on algae, coral and fish populations. Conservation Biology 10:136-154.

McClanahan, T. R., N. A. Muthiga, A. T. Kamukuru, H. Machano, and R. Kiambo. 1999. The effects of marine parks and fishing on the coral reefs of northern Tanzania. Biological Conservation 89:161-182.

McCosker, J. E., and R. H. Rosenblatt. 1984. The inshore fish fauna of the Galápagos Islands. Pages 133-144 in R. Perry, editor. Key environments: Galápagos. Pergamon Press, Oxford, United Kingdom.

McCormick, M., and J. Choat. 1987. Estimating total abundance of a large temperate reef fish using visual strip-transects. Marine Biology 96:469-478.

Merlen, G. 1995. Use and misuse of the seas around the Galápagos Archipelago. Oryx 29:99-106.

Reck, G. 1983. The coastal fisheries in the Galápagos Islands, Ecuador. Ph.D. dissertation. Mathematisch-Naturwissenschaftlichen Fakaltät der Christian-Albrechts-Universität zu Kiel, Bremerhaven, Germany.

Rice, W. R. 1990. A consensus combined probability test and the family-wide significant of component tests. Biometrics 46:303-308

Russ, G. 1991. Coral reef fisheries: effects and yields. Pages 601-635 in P. Sale, editor. The ecology of fishes on coral reefs. Academic Press, San Diego, California.

Russ, G., and A. Alcala. 1989. Effects of intense fishing pressure on an assemblage of coral reef fishes. Marine Ecology Progress Series 56:13-27.

Sala, E., C. F. Boudouresque, and M. Harmelin-Vivien. 1998. Fishing, trophic cascades, and the structure of algal assemblages: evaluation of an old but untested paradigm. Oikos 82:425-439.

Sala, E. and M. Zabala. 1996. Fish predation and the structure of the sea urchin Paracentrotus lividus populations in the NW Mediterranean. Marine Ecology Progress Series 140:71-81.

Sale, P., and B. Sharp. 1983. Correction for bias in visual transect censuses of coral reef fishes. Coral Reefs 2:37-42.

Samoilys, M. A. 1997. Underwater visual census surveys. Pages 16-29 in M. Samoilys, editor. Manual for assessing fish stocks on pacific coral reefs. Department of Primary Industries, Brisbane, Queensland, Australia.

Sissenwine, M. P. 1984. Why do fish populations vary? Pages 59-94 in R. May, editor. Exploitation of marine communities. Springer-Verlag, New York.

Watson, M., and R. Ormond. 1994. Effect of an artisanal fishery on the fish and urchin populations of a Kenyan coral reef. Marine Ecology Progress Series 109:115-129.

Watson, R. A., G. M. Carlos, and M. A. Samoilys. 1995. Bias introduced by the non-random movement of fish in visual transect surveys. Ecological Modelling 77:205-214.

Wellington, G. M. 1984. Marine environment and protection. Pages 247-263 in J. E. Treherne and R. Perry, editors. Key environment series: Galápagos Islands. Pergamon Press, Oxford, United Kingdom.

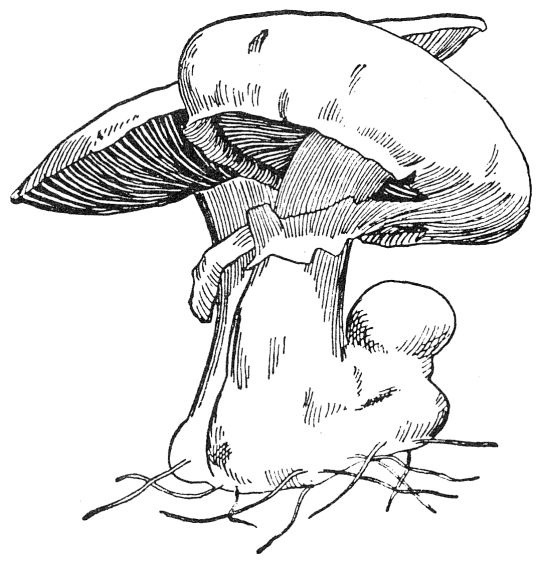

